\title{
Anti-inflammatory Effect of Oxya chinensis sinuosa Ethanol Extract in LPS-induced RAW 264.7 Cells
}

\author{
Young-ll Yoon ${ }^{1}$, Mi Yeon Chung ${ }^{1}$, Jae-Sam Hwang ${ }^{1}$, Tae-Won Goo ${ }^{1}$, Mi-Young Ahn ${ }^{1}$, Young-Bo Lee ${ }^{1}$, \\ Myung-Sea $\mathrm{Han}^{2}$ and Eun-Young Yun ${ }^{1 *}$
}

\author{
${ }^{1}$ Department of Agricultural Biology, National Academy of Agricultural Science, RDA, Suwon 441-100, Korea \\ ${ }^{2}$ Department of Bio Materials and Fiber Science, Kyungpook National University, Daegu 702-701, Korea
}

Received March 14, 2014 /Revised March 17, 2014 / Accepted March 26, 2014

\begin{abstract}
Although the grasshopper Oxya chinensis sinuosa has long been used as food in Korea, there is little data on its functional effects. In this study, we investigated the anti-inflammatory effect of $O$. c. sinuosa ethanol extract (OCE) in RAW 264.7 mouse macrophage cells treated with lipopolysaccharide (LPS) for induction of inflammation. First, we determined that there is no cytotoxicity at $2,000 \mu \mathrm{g} / \mathrm{ml}$ or less of OCE in RAW 264.7 cells. To evaluate the anti-inflammatory effects of OCE, we investigated expression levels of pro-inflammatory cytokines such as tumor necrosis factor (TNF)- $\alpha$ and interleukin (IL)-6, and pro-inflammatory enzymes such as inducible nitric oxide synthase (iNOS) and cyclo-oxygenase-2 (COX-2) in LPS-induced RAW 264.7 cells. In addition, we examined whether OCE could inhibit translocation of NF-kB p65 into the nucleus in LPS induced RAW 264.7 cells. As a result, we found that the mRNA and protein levels of TNF- $\alpha$ and IL-6 decreased in LPS-induced RAW 264.7 cells after treatment with OCE in a dose-dependent manner. In addition, we confirmed a 2,000 ug/ml concentration of OCE inhibited translocation of NF-кB p65 by immunnostaining and Western blot analysis, and a decrease in the protein expression levels of iNOS and COX-2. Accordingly, we suppose that OCE has an anti-inflammatory effect through down-regulation of TNF- $\alpha$, IL-6, iNOS, and COX-2 related to NF-kB p65 inflammatory signaling pathways.
\end{abstract}

Key words : Cyclo-oxygenase-2 (COX-2), inducible nitric oxide synthase (iNOS), lipopolysaccharide, NF-кB p65, Oxya chinensis sinuosa, pro-inflammatory cytokine, RAW 264.7 cells

\section{서 론}

염증반응은 상처와 외부 이물질의 침입 시 생체를 방어하 기 위해 가장 먼저 일어나는 선천성 면역(innate immunity) 반응이며[8], 염증의 작용과 기간에 따라 급성염증과 만성염 증 반응으로 나눌 수 있다. 급성염증 반응은 외부 이물질로 인한 자극에 의해 대식세포(macrophage)가 활성화되어 생성 된 염증매개물질인 염증성 사이토카인(cytokine), chemokine, nitric oxide (NO) 및 prostaglandin E2 (PGE2) 등을 생성하여 이들에 의해 활성화된 백혈구와 대식세포에 의해 이물질을 제거한 후 조직재생을 통해 종료된다[22]. 급성염증 반응은 생체를 방어하기 위한 필수적인 반응이지만, 이 반응에서 과 도하게 분비된 염증매개물질은 과도한 혈관확장으로 급성 패 혈성 쇼크를 일으킬 수 있으며, 면역세포의 지속적인 생존과

\footnotetext{
*Corresponding author

Tel : +82-31-290-8576, Fax : +82-31-290-8543

E-mail : yuney@korea.kr

This is an Open-Access article distributed under the terms of the Creative Commons Attribution Non-Commercial License (http://creativecommons.org/licenses/by-nc/3.0) which permits unrestricted non-commercial use, distribution, and reproduction in any medium, provided the original work is properly cited
}

활성을 일으켜 만성염증이나 면역과민반응의 원인이 되어 류 마치스 관절염과 같은 만성염증질환 및 자가면역질환으로 발 전될 수 있으므로 $[8,11,13,29]$, 염증반응 조절은 생명현상 유지를 위해 매우 중요하다.

면역세포에는 대식세포, 단핵구, 백혈구 및 비만세포 등이 있으며, 이 중 대식세포는 모든 조직에 존재하며 체내 유입된 염증의 원인을 가장 먼저 인식한 후 염증매개물질을 생성하 여 다른 면역세포의 활성화 및 주화성을 유도시켜 염증원인 을 제거하고 염증부위를 복구시키는 등 염증과정에 필수적인 역할을 수행한다. 대식세포는 pathogen-associated molecular patterns (PAMPS)에 속해있는 그람 음성세균의 세포벽 성분 인 LPS 처리시 표면에 있는 toll like receptor-4 (TLR-4)가 이 를 인식한 후 Toll/IL-1 receptor domain (TIR)과 myeloid differentiation primary response gene 88 (MYD88)로 신호를 전달하여 활성화된 MYD88 단백질은 IL-1 receptor associated kinase-4 (IRAK-4)를 TLR-4에 결합시키고 TNF receptor associated factor-6 (TRAF-6)를 유도시킨다. TRAF-6는 $\mathrm{I} \kappa \mathrm{K}$ (I kappaB kinase)를 활성화시켜 세포질에 존재하는 전사 인자인 NF-kB p50/p65에 결합되어 있는 $\mathrm{I} \kappa \mathrm{Ba}$ 가 분해되어 $\mathrm{NF}-\kappa \mathrm{B} \mathrm{p} 50 / \mathrm{p} 65$ 는 핵으로 이동된다. 핵으로 이동된 NF- $\mathrm{kB}$ $\mathrm{p} 50 / \mathrm{p} 65$ 전사인자는 염증성 사이토카인인 TNF-a 및 IL-6와 
염증성 효소인 iNOS 및 COX-2를 발현시킨다 $[3,9,12,22$, 25].

TNF- $a$ 는 내분비와 외분비를 통해 자신과 다른 대식세포의 TNF- $a$ 수용체(TNFR)에 리간드(ligand)로 결합하여 NF-kB $\mathrm{p} 50 / \mathrm{p} 65$ 를 활성화시켜 염증성 사이토카인인 TNF-a 및 IL-6 와 $\mathrm{iNOS}, \mathrm{COX}-2$ 를 발현시킨다 $[7,9,22,25]$. IL-6는 JAK-STAT (Janus kinase-signal transducer and activator of transcription) 신호전달과정을 활성화시켜 백혈구와 후천성 면역(acquired immunity)과 관련된 림프구인 T 및 B 세포를 자극하여 급성염증을 만성염증으로 전환시킨다 $[5,30]$. $\mathrm{NO}$ 는 $\mathrm{iNOS}$ 에 의해 생성되며 정상적인 상태에서는 방어작용과 신 경전달물질 및 혈관 조절 등의 기능을 하지만 염증과정에서 대량 생성된 $\mathrm{NO}$ 는 급성 패혈성 쇼크를 일으킬 수 있으며 강 한 독성을 갖고 있어 다양한 세포 및 조직에 손상을 일으켜 만성염증과 자가면역질환의 원인이 된다[12, 14]. COX-2는 세 포막의 인지질에서 유래한 아라키돈산(arachidonic acid)을 PGE2로 전환시켜 혈관확장과 투과성을 증가시키고, 감각신 경세포에 작용하여 통증을 생성시키는 등 염증 반응에 매우 중요한 역할을 수행한다[6, 17, 27].

벼메뚜기(Oxya chinensis sinuosa)는 우리벼메뚜기라고도 불리는 메뚜기목 메뚜기과 벼메뚜기속의 불완전변태 곤충으 로 몸길이는 21 35 mm이고 8 10월에 출현하며, 국내에서 오 랫동안 식용으로 이용되어 왔다[18]. 하지만, 벼메뚜기의 기능 성에 대한 연구는 산화적 스트레스를 유도한 신경아종 세포 주인 SH-SY5Y에 대한 항산화 활성과 COX-2 전사 억제에 대 한 보고 외에는 전무한 실정이다[19]. 이에 본 연구에서는 식 용으로 이용되는 벼메뚜기에 대한 기능성 연구의 일환으로 LPS로 염증이 유도된 RAW 264.7 세포에 벼메뚜기 에탄올 추 출물을 처리하여 벼메뚜기의 항염증 효능을 검증하였다.

\section{재료 및 방법}

\section{벼메뚜기 및 강황 추출물 제조}

추출물 제조를 위해 사용된 벼메뚜기(Oxya chinensis sinuOSa)는 강원도 영월군 영월읍 영흥리에서 채집된 것을 사용하 였고 양성대조군으로 사용한 강황은 시중에서 판매되고 있는 국내산 건조 강황(Curcuma longa)을 구매하였다. 벼메뚜기 및 강황은 흐르는 물에 2회 세척한 후, 동결 건조기(Eyela, Japan)를 이용하여 건조시켜 수분을 제거하고 다기능 분쇄기 (Korea Medi, Korea)로 분쇄하여 분말을 제조하였다. 분말 현 탁액 제조를 위해 분말을 $70 \%$ 에탄올에 용해시킨 후 초음파 파쇄기(LabaX, MA, USA)로 230 jule, 20초간 파쇄 후 4500 $\mathrm{rpm}$ 에서 10 분 동안 원심분리하고 회수한 상층액을 $0.25 \mu \mathrm{m}$ syringe filter (Whatman, ND, USA)로 여과 후 건조하여 시 료로 사용하였다.

\section{세포 생존률 분석}

RAW 264.7 세포는 penicillin-streptomycin $100 \mathrm{unit} / \mathrm{ml}$ 과 $10 \%$ fetal bovine serum (Gibco, $\mathrm{MD}, \mathrm{USA}$ )이 함유된 Dublecco's Modified Eagle Medium (Gibco, MD, USA) 배지 를 사용하여 $37^{\circ} \mathrm{C}, 5 \% \mathrm{CO}_{2}$ incubator (Thermo Scientific, IL, $\mathrm{USA}$ )에서 배양하였으며, 2일 간격으로 계대 배양을 실시하였 다. 세포 생존율 측정을 위해 RAW 264.7 세포를 $2 \times 10^{5}$ cells $/ \mathrm{ml}$ 로 96 well plate에 분주하고 벼메뚜기 추출물을 농도 별 $(100,500,1,000,2,000 \mathrm{\mu g} / \mathrm{ml})$ 로 처리 후 $37^{\circ} \mathrm{C}, 5 \% \mathrm{CO}_{2}$ incubator에서 24시간 배양하였다. CellTiter $96^{\circledR}$ aqueous non-radioactive cell proliferation assay reagent (Promega, $\mathrm{WI}, \mathrm{USA}$ )를 첨가한 후, $37^{\circ} \mathrm{C}, 5 \% \mathrm{CO}_{2}$ incubator에서 4 시간 반응시켜 microplate reader (Beckman Coulter, CA, USA)를 이용하여 $450 \mathrm{~nm}$ 에서 흡광도를 측정하여 세포 생존율을 측 정하였다.

\section{Real-time PCR 분석}

염증성 사이토카인 유전자의 전사(transcription)에 미치는 $\mathrm{OCE}$ 의 효과를 검증하기 위해서 real-time PCR을 수행하였 다. $100 \mathrm{ng} / \mathrm{ml}$ 의 LPS (Sigma, MO, USA)로 RAW 264.7 세포 를 자극하고, OCE를 농도별 $(100,500,1,000,2,000 \mu \mathrm{g} / \mathrm{ml})$ 로 처리한 후 $37^{\circ} \mathrm{C}, 5 \% \mathrm{CO}_{2}$ incubator에서 24시간 배양하였다. 세포를 PBS로 2회 세척 후 trizol reagent (Invitrogen, CA, $\mathrm{USA}$ )를 이용하여 세포에서 total RNA을 추출한 후, high capacity cDNA reverse transcription kit (Applied Biosystems, $\mathrm{IL}, \mathrm{USA}$ )를 이용하여 $\mathrm{cDNA}$ 를 합성하였다. 합성된 $\mathrm{cDNA}$ 는 Power SYBR ${ }^{\circledR}$ Green Maser Mix (Applied Biosystems, IL, USA)를 이용하여 7500 Real-time Thermal Cycler (Applied Biosystems, IL, USA)를 통해 TNF-a 및 IL-6 유전자를 증폭시 켰으며, 이때 사용한 프라이머(primer)는 Table 1에 나타내었 다. Glyceraldehyde 3-phospate dehydrogenase (GAPDH)를 endogenous control로 사용하여 GAPDH 대비 TNF-a 및 IL-6 mRNA의 발현량을 ddCT method를 통해 상대정량 분 석하였다.

Enzyme-linked immunosorbent assay (ELISA) 분석

TNF-a 및 IL-6와 같은 염증성 사이토카인 생성에 미치는 $\mathrm{OCE}$ 의 효과를 검증하기 위해서 $100 \mathrm{ng} / \mathrm{ml}$ 의 LPS로 $\mathrm{RAW}$

Table 1. Sequences of primer used in real-time PCR analysis

\begin{tabular}{|c|c|c|}
\hline \multicolumn{2}{|c|}{ Name } & Sequences \\
\hline GAPDH & & $\begin{array}{l}\text { 5'-GCCTCACCCCATTTGATGTT-3' } \\
5^{\prime} \text {-GGGAAGCCCATCACCATCT-3' }\end{array}$ \\
\hline IL- 6 & & $\begin{array}{l}5^{\prime} \text {-TTGGGAGTGGTATCCTCTGT-3' } \\
5^{\prime} \text {-CCACGGCCTTCCCTACTTC-3' }\end{array}$ \\
\hline TNF- $a$ & $\begin{array}{l}\text { Forward } \\
\text { Reverse }\end{array}$ & $\begin{array}{l}\text { 5'-ACAGCACCGCAGTACCTGAG-3' } \\
5^{\prime} \text {-CCACGGCCTTCCCTACTTC-3' }\end{array}$ \\
\hline
\end{tabular}


264.7 세포를 자극하고, OCE를 농도 별(100, 500, 1,000, 2,000 $\mu \mathrm{g} / \mathrm{ml}$ 로 처리한 후 $37^{\circ} \mathrm{C}, 5 \% \mathrm{CO}_{2}$ incubator에서 24 시간 배 양하였다. 이 후 배양액을 회수하여 TNF-a 및 IL-6 ELISA kit (Thermo Scientific, IL, USA)을 이용하여 TNF- $a$ 및 IL-6의 사 이토카인 생성량을 microplate reader (Beckman Coulter, (A, USA)를 통해 $450 \mathrm{~nm}$ 의 파장에서 측정하였다.

\section{NF- $\mathrm{kB}$ p65 면역형광염색}

LPS에 의해 활성화되는 염증관련 전사인자 NF-kB p65에 대한 OCE의 효능을 검증하기 위해서 LPS (Sigma, MO, USA) $100 \mathrm{ng} / \mathrm{ml}$ 의 농도로 RAW 264.7 세포를 자극하고, OCE를 농 도별 $(100,2,000 \mu \mathrm{g} / \mathrm{ml})$ 로 처리한 후 $37^{\circ} \mathrm{C}, 5 \% \mathrm{CO}_{2}$ incubator 에서 1시간 배양하였다. 배양된 세포는 phosphate buffered saline (PBS) (Sigma, MO, USA)으로 2회 세척 후 formaldehyde (Sigma, MO, USA)를 이용하여 상온에서 25분 동안 세포를 고정시켰다. 고정된 세포는 계면활성제인 $0.01 \%$ Triton X-100 (Sigma, MO, USA)을 이용하여 항체의 세포막 투과성을 증대시킨 다음 5\% horse serum (Vector Labs, CA, USA)을 이용하여 상온에서 1시간 동안 blocking 과정을 수행 하였다. NF-kB p65 1차 항체(Santa Cruz, CA, USA)를 1:1,000 의 배율로 희석하여 $4^{\circ} \mathrm{C}$ 에서 밤새 배양 후 상온에서 $\mathrm{PBS}$ 로 10 분씩 4 회 세척하고 12,000 의 비율로 희석한 2 차 항체 alexa fluor 488 (Molecular Probes, MD, USA)로 2시간 동안 상온 에서 반응시켰다. 반응된 세포는 $\mathrm{PBS}$ 로 상온에서 10 분씩 4 회 세척 후 VECTA SHIELD (Vector Labs, CA, USA) 용액과 함 께 슬라이드글라스에 부착시켜 DMI6000B 형광현미경(Leica, $\mathrm{NJ}, \mathrm{USA}$ )을 이용하여 확인하였다.

\section{Western blot 분석}

염증성 효소인 iNOS와 COX-2의 생성에 미치는 OCE의 효 과를 검증하기 위해 $100 \mathrm{ng} / \mathrm{ml}$ 농도의 LPS로 염증 유도된 RAW 264.7 세포에 OCE를 100, 500, 1,000, 2,000 $\mathrm{\mu g} / \mathrm{ml}$ 의 농 도로 처리하고 $37^{\circ} \mathrm{C}, 5 \% \mathrm{CO}_{2}$ incubator에서 24 시간 배양 후 세포에서 단백질을 분리하여 Western blot 분석을 수행하였 다. 세포를 PBS로 2회 세척 후 cell scraper (SPL Life Science, Korea)로 모은 다음 Cytobuster ${ }^{\mathrm{TM}}$ Protein Extraction Reagent (Novagen, ND, USA)를 이용하여 세포를 분쇄한 후, 12,000 $\mathrm{rpm}$ 에서 15 분간 원심 분리하여 상층액을 회수하였다. 회수한 상층액은 Bio Rad Protein Assay (Bio Rad, CA, USA)로 농도 를 측정하고 $10 \mu \mathrm{g} / \mathrm{ml}$ 의 농도로 맞춘 후 $10 \%$ SDS-PAGE를 수행하였다. 전기영동 후 PVDF membrane (GE Healthcare, $\mathrm{NJ}, \mathrm{USA}$ )에 transfer하고, Blotting Grade Blocker (Bio Rad, $\mathrm{CA}, \mathrm{USA}$ )를 TBST에 녹여 $5 \%$ 의 농도로 만든 다음 이를 이용 하여 PVDF membrane을 1시간 동안 상온에서 blocking시켰 다. 1차 항체 COX-2 (Santa Cruz, CA, USA)와 iNOS (Abcam, MA, USA)는 1:1,000으로, $\beta$-Actin (Sigma, MO, USA)은
$1: 10,000$ 의 비율로 희석하여 $4^{\circ} \mathrm{C}$ 에서 밤새 반응시킨 후 다음 날 TBST로 15분씩 4번 세척하였다. 2차 항체 HRP-conjugated secondary antibody (Promega, WI, USA)는 1:3,000 의 비율로 40 분 동안 상온에서 반응 시킨 후 다시 TBST로 15 분씩 4번 세척하였다. Western Lightning ${ }^{\circledR}$ Plus ECL (Perkin Elmer, MA, USA)을 PVDF membrane에 처리 후 암실에서 $\mathrm{X}$-ray 필름(Fujifilm, Japan)으로 감광시켜 iNOS와 COX-2의 단백질 발현량을 확인하였다.

\section{결과 및 고찰}

\section{세포 독성 여부 확인}

벼메뚜기 에탄올 추출물(OCE)을 RAW 264.7 대식세포에 농도별 $(100,500,1,000,2,000 \mu \mathrm{g} / \mathrm{ml})$ 로 처리한 후 MTS assay 로 세포 생존율을 확인하였다. 그 결과 OCE는 2,000 $\mathrm{\mu g} / \mathrm{ml}$ 의 농도까지 세포 생장에 영향을 주지 않아 독성이 없음을 확인 하였다. 본 실험에서는 기존에 항염증 효능이 보고된 강황 $(C$. longa) 을 양성대조군으로 사용하였으며[1], 강황은 본 실험에 서 사용한 벼메뚜기 시료와 동일한 방법으로 에탄올 추출물 (CLE) 제조 후 $1,000 \mu \mathrm{g} / \mathrm{ml}$ 의 농도까지 세포독성이 나타나지 않음을 확인하였다(Fig. 1). 따라서, 본 연구에서 사용한 $\mathrm{OCE}$ 및 CLE의 최고 농도는 각각 RAW 264.7 세포에 독성을 나타 내지 않는 2,000 및 $1,000 \mu \mathrm{g} / \mathrm{ml}$ 로 사용하였다.

\section{OCE의 염증성 사이토카인 발현에 미치는 영향 분석}

$\mathrm{OCE}$ 의 항염증 효능을 분석하기 위해 RAW 264.7 세포에 LPS로 염증 유도 후 OCE를 처리하고 염증성 사이토카인의 발현을 전사체 및 단백질 수준에서 각각 real-time PCR 및 ELISA에 의해 확인하였다(Fig. 2, Fig. 3). PAMPS의 일종인

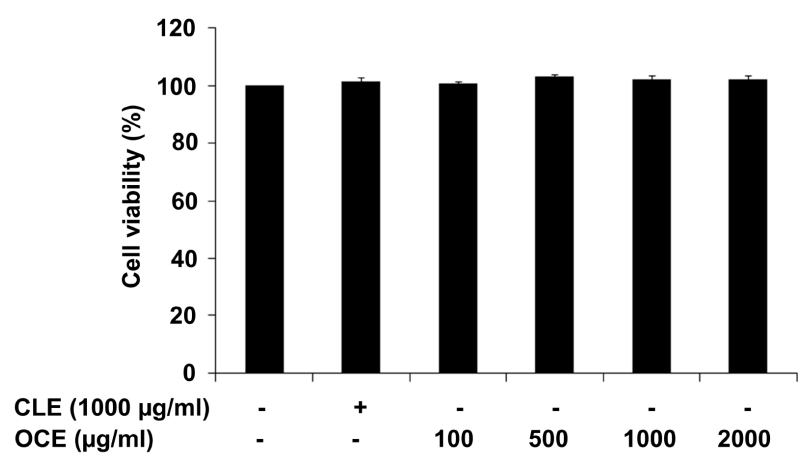

Fig. 1. Viability of RAW 264.7 cells after treatment with OCE (Oxya chinensis sinuosa ethanol extract) and CLE (Curcuma longa ethanol extract) for $24 \mathrm{hr}$. Cell viability was determinded by (3-(4,5-dimethylthiazol-2-yl)-5-(3-carboxy methoxyphenyl)-2-(4-sulfophenyl)-2H-tetrazolium) tetrazolium (MTS) colormetric assay. OCE has no cell toxicity at $2,000 \mu \mathrm{g} / \mathrm{ml}$ concentration. The values are expressed as means $\pm \operatorname{SD}(n=4)$. 
LPS 처리시 대식세포 표면에 존재하는 TLR-4가 이를 인식하 고 활성화되어 염증매개물질을 발현시키므로 $[9,22,25]$, 우선 염증성 사이토카인인 TNF- $a$ 와 IL-6에 대한 발현량을 전사체 수준에서 확인하였다. TNF- $a$ 의 경우 LPS 처리시 LPS 무처리 군에 비해 약 7.5배 발현량이 증가되었고, LPS와 $2,000 \mu \mathrm{g} / \mathrm{ml}$ OCE 동시처리시 LPS 단독처리군에 대비 약 3.3배 유전자 발 현이 감소됨을 확인할 수 있었다(Fig. 2A). IL-6는 LPS 단독처 리군에서 무처리군 대비 약 21.4배 유전자 발현이 증가되었 고, LPS와 2,000 $\mathrm{\mu g} / \mathrm{ml} \mathrm{OCE} \mathrm{동시처리시} \mathrm{LPS} \mathrm{단독처리} \mathrm{군에}$ 비해 약 10.4 배 발현이 억제됨을 확인하였다(Fig. 2B). 양성대 조군으로 사용된 CLE의 경우 세포 독성을 나타내지 않는 $1,000 \mu \mathrm{g} / \mathrm{ml}$ 의 농도로 LPS와 동시 처리시 LPS 단독처리군 대비 TNF-a는 약 2.8배, IL-6는 약 1.7배 발현이 감소되었고, 동일농도의 OCE와 LPS 동시처리시 TNF-a는 약 3.1배, IL-6 는 약 2.4배 발현이 감소되었으므로 염증이 유도된 대식세포 에서 OCE가 CLE보다 염증성 사이토카인 발현을 보다 강하 게 억제함을 확인할 수 있었다.

또한, LPS로 유도된 RAW 264.7 세포에 OCE를 농도별
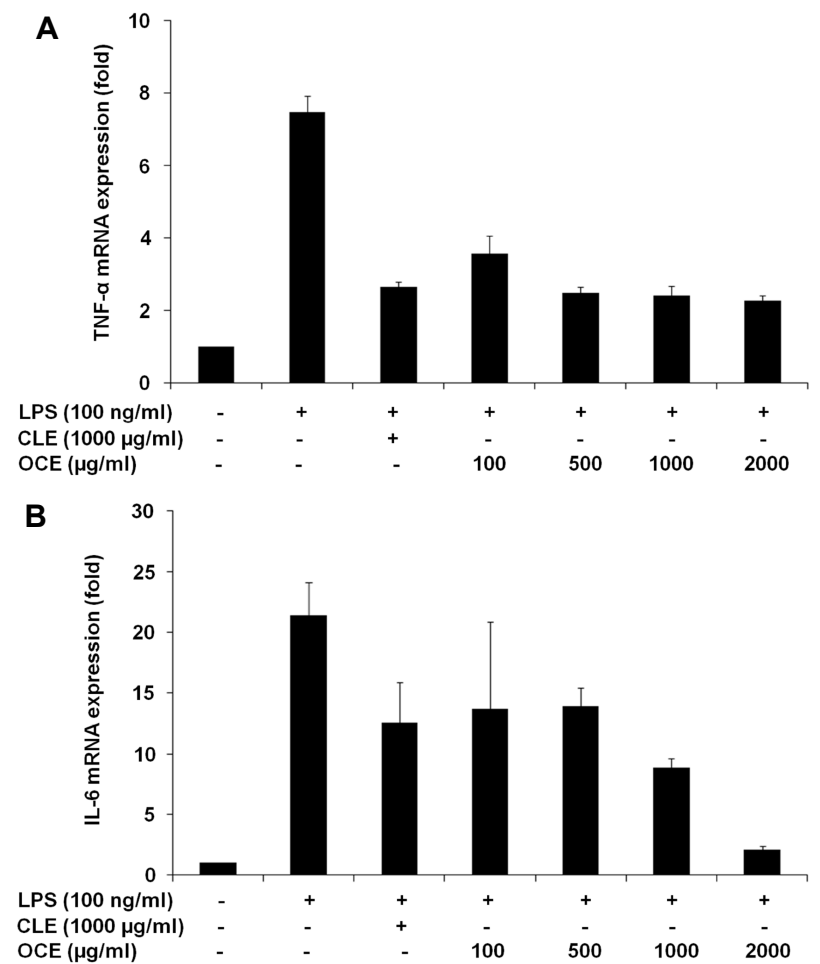

Fig. 2. Effect of OCE (Oxya chinensis sinuosa ethanol extract) on TNF-a (A) and IL-6 (B) mRNA expression in LPS-induced RAW 264.7 cells. The cells were co-treated with OCE $(100-2,000 \mu \mathrm{g} / \mathrm{ml})$ and with or without LPS (100 $\mathrm{ng} / \mathrm{ml}$ ) for $24 \mathrm{hr}$. TNF-a and IL-6 mRNA expression were decreased in LPS-induced RAW 264.7 cells after treatment with OCE in a dose-dependent manner. The values are expressed as means $\pm \operatorname{SD}(n=4)$.
$(100,500,1,000,2,000 \mu \mathrm{g} / \mathrm{ml})$ 로 처리한 후 배양액 내에서의 ELISA 분석을 통해 염증성 사이토카인의 단백질 발현 후 세 포 외 분비량을 확인한 결과, $\mathrm{OCE}$ 처리에 의해 농도 의존적 으로 감소함을 확인할 수 있었다. LPS 처리 시 LPS 무처리군 에 비해 TNF-a는 약 59.7배, IL-6는 약 34.6배 증가됨을 확인 할 수 있었다. 2,000 $\mathrm{mg} / \mathrm{ml} \mathrm{OCE} \mathrm{처리} \mathrm{시} \mathrm{LPS} \mathrm{단독처리군에}$ 비해 TNF-a는 약 10.8 배, IL-6는 약 7.9배 감소됨을 확인할 수 있었다(Fig. 3). 양성대조군으로 사용된 $1,000 \mu \mathrm{g} / \mathrm{ml} \mathrm{CLE} \mathrm{처}$ 리시 LPS 단독처리군에 비해 TNF- $a$ 는 약 1.9 배, IL-6는 약 2.4 배 감소됨을 확인할 수 있었다. 한편 동일 농도인 $1,000 \mu$ $\mathrm{g} / \mathrm{ml} \mathrm{OCE}$ 처리시 LPS 단독처리군에 비해 TNF- $a$ 는 약 4.6배, IL-6는 약 2.5배 감소됨을 확인함으로써, 전사체 발현뿐만 아 니라 단백질 발현 후 세포 외 분비량 또한 OCE 처리시 CLE 처리시 보다 감소됨을 확인할 수 있었다.

$\mathrm{TNF}-a$ 는 주로 활성화된 대식세포에서 생성되어 염증반응 에서 다른 면역세포의 TNFR에 결합하여 염증매개물질의 발 현을 증가시키는 등의 역할을 수행하고[6, 7], IL-6는 IL-6 수 용체(receptor)에 결합하여 후천성면역과 관계된 림프구를 활
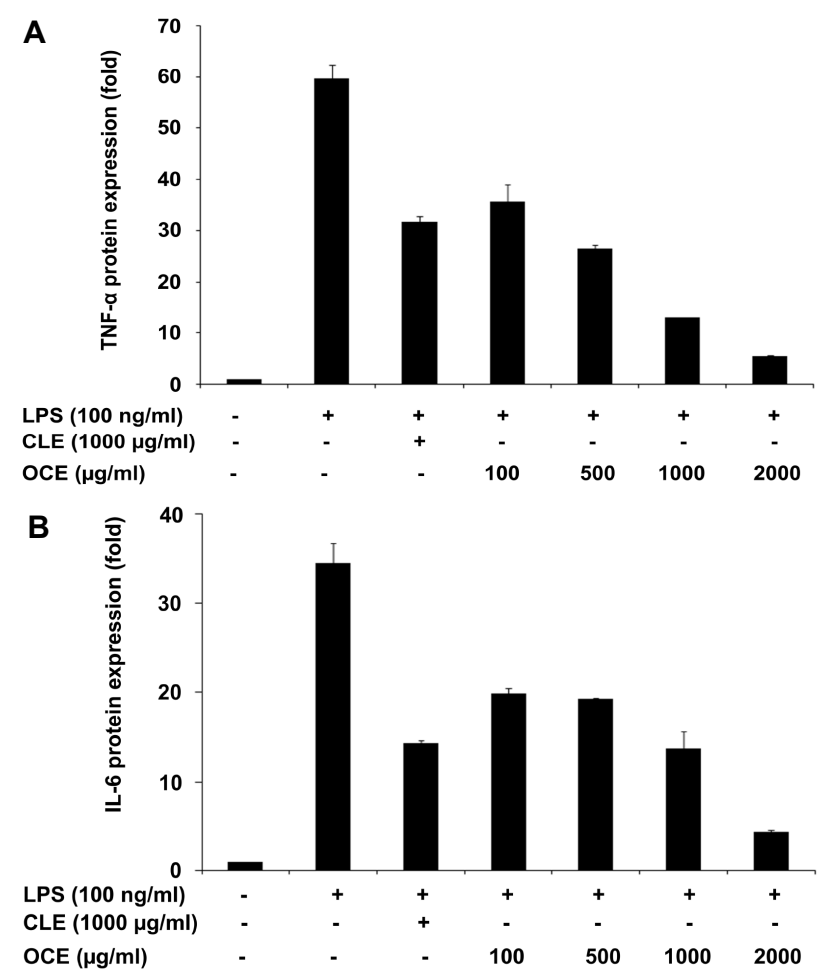

Fig. 3. Effect of OCE (Oxya chinensis sinuosa ethanol extract) on LPS-induced TNF-a (A) and IL-6 (B) protein expression on in RAW 264.7 cells. The cells were co-treated with OCE $(100-2,000 \mu \mathrm{g} / \mathrm{ml})$ and with or without LPS (100 $\mathrm{ng} / \mathrm{ml}$ ) for $24 \mathrm{hr}$. TNF-a and IL-6 protein expression were decreased in LPS-induced RAW 264.7 cells after treatment with OCE in a dose-dependent manner. The values are expressed as means $\pm \operatorname{SD}(n=4)$. 
성화시키는 역할을 한다 $[5,30]$. 그러나 과도하게 분비된 TNF-a 및 IL-6는 면역계 항상성의 불균형을 초래하여 다양한 세포와 조직에 기능저해를 일으켜 제 2형 당뇨, 염증성 장질 환, 류마치스 등과 같은 만성염증 및 자가면역질환을 유발할 수 있으므로 염증성 사이토카인인 TNF- $a$ 와 IL-6의 생성을 조 절할 수 있는 물질은 만성염증 및 자가면역질환에 대한 치료 제로 사용될 수 있다 $[4,5,22,30]$. 본 연구에서 사용한 OCE는 염증매개물 중 하나인 염증성 사이토카인을 강하게 억제하므 로 항염증 효능을 갖고 있을 뿐만 아니라 OCE 처리시 기존에 항염증 효능이 보고된 강황을 동일한 농도로 처리한 경우 보 다 TNF-a 및 IL-6 분비량이 감소됨을 확인할 수 있으므로 천 연물 유래 항염증 물질로 사용될 수 있을 것이라 사료된다.

\section{$\mathrm{OCE}$ 의 NF- $\mathrm{kB} \mathrm{p} 65$ 활성화 억제 확인}

OCE 처리 후 LPS 및 TNF-a에 의해 활성화되며 신호전달 과정에서 염증매개물질의 상류에 존재하는 전사인자 NF-kB p65의 활성화 억제 여부를 확인하기 위해 LPS로 염증 유도된 RAW 264.7 세포에 OCE를 농도별 $(100,2,000 \mu \mathrm{g} / \mathrm{ml})$ 처리 후 면역형광염색을 통해 NF-kB p65의 세포 내 위치를 확인하였 다. NF-kB p65는 염증이 유도되지 않을 경우에는 IkBa와 결 합된 상태로 세포질에 존재하여 염증매개물질관련 유전자 전 사를 활성화시킬 수 없지만, LPS 및 TNF- $a$ 에 의한 신호전달 이 활성화 되면 $\mathrm{I} k \mathrm{Ba}$ 가 분해되고 NF-kB p65가 핵으로 이동하 여 염증매개물질 유전자의 프로모터에 존재하는 NF-kB element에 결합하여 전사를 활성화 시킨다 $[9,25]$.

염증 유도된 RAW 264.7 세포에 2,000 $\mathrm{\mu g} / \mathrm{ml} \mathrm{OCE} \mathrm{처리}$ 후 NF-kB p65 항체로 면역형광염색 결과 NF-kB p65는 대부 분 핵으로 이동되지 않고 세포질에 존재하였으므로 OCE에 의해 NF-kB p65 활성화가 억제되었음을 확인할 수 있었다 (Fig. 4). 또한 NF-kB p65 활성이 억제되었으므로 IL-1B와 같 은 다른 염증성 사이토카인이나 면역세포의 주화성을 증가시 키는 chemokine 등의 생성도 추가로 차단할 것이라 추정된다.

\section{OCE의 iNOS 및 COX-2 단백질 발현 억제 확인}

LPS 처리시 대식세포 표면에 있는 TLR-4 (toll like receptor-4)에 의해 활성화되어 발현되는 염증성 효소인 $\mathrm{NNOS}$ 와 COX-2의 발현 억제를 통한 항염증 효능을 확인하기 위해, LPS로 염증 유도된 RAW 264.7 세포에 OCE를 100, 500, $1,000,2,000 \mu \mathrm{g} / \mathrm{ml}$ 의 농도로 처리한 후 iNOS와 COX-2 단백 질 발현량을 Western blot 분석을 통해 확인하였다. iNOS와 COX-2 단백질 모두 2,000 $\mathrm{\mu g} / \mathrm{ml} \mathrm{OCE}$ 처리시 단백질 발현이 현저히 감소된 것을 확인하였다(Fig. 5).

$\mathrm{NO}$ 는 염증반응에서 혈관확장과 외부 이물질에 대한 방어 기능을 수행하지만[23,30], 염증성 사이토카인에 의해 과도하 게 분비된 $\mathrm{NO}$ 는 $\mathrm{DNA}$ 손상, 염증매개물 과다 생성을 통한 염 증 증폭, 과도한 혈관확장으로 인한 패혈성 쇼크, 강한 세포독

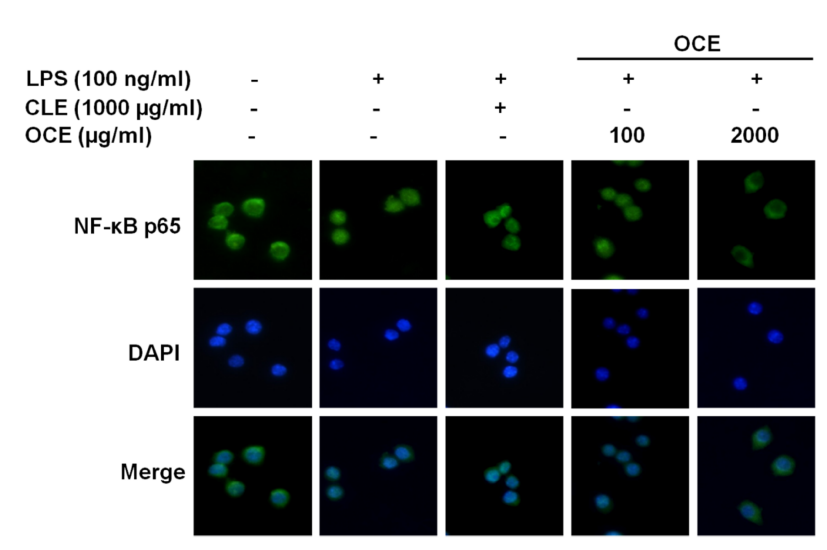

Fig. 4. Effect of OCE (Oxya chinensis sinuosa ethanol extract) on LPS-induced NF- $\kappa \mathrm{B}$ p 65 translocation into the nucleus. The cell were co-treated with OCE $(100,2,000 \mu \mathrm{g} / \mathrm{ml})$ and with or without LPS $(100 \mathrm{ng} / \mathrm{ml})$ for $1 \mathrm{hr}$. The 2,000 $\mu \mathrm{g} / \mathrm{ml}$ concentration of OCE inhibited on LPS induced NF- $\kappa B$ p 65 translocation into the nucleus.

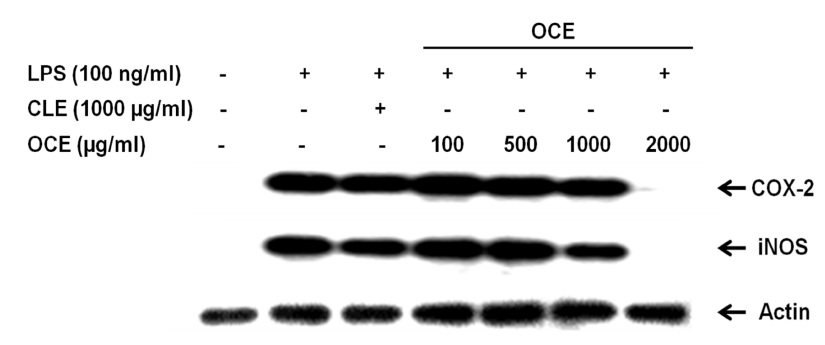

Fig. 5. Effect of OCE (Oxya chinensis sinuosa ethanol extract) on COX-2 and iNOS protein expression in LPS-induced RAW 264.7 cells. The cell were co-treated with OCE $(100-2,000 \mu \mathrm{g} / \mathrm{ml})$ and with or without LPS $(100 \mathrm{ng} / \mathrm{ml})$ for $24 \mathrm{hr}$. The 2,000 $\mu \mathrm{g} / \mathrm{ml}$ concentration of OCE decreased COX-2 and iNOS protein expression.

성으로 인한 세포 및 조직 괴사, 기능장애 등을 일으켜 만성염 증 및 자가면역질환의 원인이 될 수 있다[16, 23, 24, 26]. 또한 NO는 COX-2와 함께 VEGF (Vascular Endothelial Growth Factor)의 생성량을 크게 증가시켜 혈관신생(angiogenesis) 효 과를 통해 종양생성에도 밀접한 관계가 있음이 보고되었다 [17].

염증반응에서 생성된 $\mathrm{NO}$ 는 $\mathrm{iNOS}$ 생성량을 통해 간접적 으로 확인할 수 있으므로[24], 본 연구에서는 염증 유도된 RAW 264.7 세포에 OCE 처리 후 Western blot 분석을 통해 iNOS 단백질 발현을 확인하였다. 그 결과 $2,000 \mu \mathrm{gg} / \mathrm{ml} \mathrm{OCE} \mathrm{처리시}$ $\mathrm{iNOS}$ 가 거의 발현되지 않음을 확인할 수 있었으며, iNOS의 발현은 LPS에 의한 NF-kB p65의 활성화에 의해 유도되기 때 문에 이 농도에서 NF-kB p65의 활성이 차단되어 iNOS의 발 현 감소가 이루어진 것으로 추정되었다(Fig. 3, Fig. 4).

$\mathrm{NF}-\mathrm{kB}$ p65와 NO에 의해 생성된 COX-2는 염증과정에서 인지질을 대사시켜 생성된 아라키돈산에서 PGE2를 생성시 키는 효소이고, $\mathrm{COX}-2$ 에 의해 생성된 $\mathrm{PGE} 2$ 는 혈관확장, 통 
증 및 발열작용을 수행한다[3]. 염증 유도된 RAW 264.7 세포 에 $2,000 \mu \mathrm{g} / \mathrm{ml} \mathrm{OCE}$ 처리 시 COX-2가 감소된 이유는 이 농 도에서 NF-kB p65의 활성화 억제를 통해 TNF-a 및 NO를 생 성하는 효소인 iNOS 단백질 발현이 현저히 감소되었기 때문 으로 추정된다.

비스테로이드성 진통제(non-steroidal anti-inflammatory drug; NSAID)의 일종인 아스피린과 indomethacin이 COX-2 의 발현 억제를 통해 항염증 효능이 있음이 발견된 이후[28], 많은 NSAID가 발명되어 항염증 치료제로 사용되어 왔다[15]. 그러나 최근 연구에 의하면 NSAID 장기간 투여 시 위장과 신장의 기능저하를 일으키며 특히, 혈관을 확장시키는 PGE2 와 prostacyclin의 생성을 억제하여 심혈관과 관련된 여러 부 작용이 보고되고 있다 $[10,13]$. 따라서 최근에는 천연물 유래 의 COX-2 억제제가 NSAID에 비해 생체에 잘 흡수되고 대사 되므로 부작용이 좀 더 적을 것으로 판단하여[6], 우유엉겅퀴 유래의 silymarin과 천연허브 6종을 혼합하여 만든 신바로 (shinbaro) 등과 같은 천연물에서 COX-2 억제제를 찾으려는 노력이 진행되고 있다[2,13]. 따라서 본 연구에서 이용한 벼 메뚜기 추출물(OCE)은 곤충 유래 천연물이며 TNF-a와 IL-6 와 같은 염증성 사이토카인과 $\mathrm{iNOS}$ 와 COX-2의 발현을 억제 하고 NF-kB p65의 활성화를 억제하므로 천연물 유래 항염증 물질로 개발될 수 있을 것이라 기대된다.

\section{감사의 글}

본 연구는 농촌진흥청에서 지원하는 어젠다 프로그램 (PJ008706, PJ010022) 및 농림수산식품부에서 지원하는 2011 년도 생명산업기술개발사업(311006-3)의 연구수행으로 인한 결과물임을 밝힙니다.

\section{References}

1. Arora, R. B., Kapoor, V., Basu, N. and Jain, A. P. 1971. Anti-inflammatory studies on Curcuma longa (turmeric). Indian J Med Res 59, 1289-1295.

2. Ahmadi-Ashtiani, H. R., Rastegar, H. and Arkam, M. 2013. The inhibitory effect of silymarin on cell viability and cellular COX-2 and iNOS level in HepG2 cell line. Health Med 7, 2008-2014.

3. Baldwin, A. S. Jr. 1996. The NF-kappa B and I kappa B proteins: new discoveries and insights. Annu Rev Immunol 14, 649-683.

4. Brennan, F. M., Chantry, D., Jackson, A., Maini, R. and Feldmann, M. 1989. Inhibitory effect of TNF alpha antibodies on synovial cell interleukin-1 production in rheumatoid arthritis. Lancet 2, 244-247.

5. Gabay, C. 2006. Interleukin-6 and chronic inflammation. Arthritis Res Ther 8, S3.

6. Cerella, C., Sobolewski, C., Dicato, M. and Diederich, M.
2010. Targeting COX-2 expression by natural compounds: a promising alternative strategy to synthetic COX-2 inhibitors for cancer chemoprevention and therapy. Biochem Pharmachol 15, 1801-1815.

7. Tracey, D., Klareskog, L., Sasso, E. H., Salfeld, J. G. and Tak, P. P. 2008. Tumor necrosis factor antagonist mechanisms of action: a comprehensive review. Pharmacol Ther 117, 244-279.

8. Ferrero-Miliani, L., Nielsen, O. H., Andersen, P. S. and Girardin, S. E. 2007. Chronic inflammation: Importance of NOD2 and NALP3 in interleukin-1beta generation. Clin Exp Immunol 147, 227-235.

9. Giuliani, C., Napolitano, G., Bucci, I., Montani, V. and Monaco, F. 2001. NF- $\kappa B$ transcription factor: role in the pathogenesis of inflammatory, autoimmune, and neoplastic diseases and therapy implications. Clin Ter 152, 249-253.

10. Howes, L. G. 2007. Selective COX-2 inhibitors, NSAIDs and cardiovascular events - is celecoxib the safest choice? Ther Clin Risk Manag 3, 831-845.

11. Iwalewa, E. O., McGaw, L. J., Naidoo, V. and Eloff, J. N. 2007. Inflammation: the foundation of diseases and disorders. A review of phytomedicines of south african origin used to treat pain and inflammatory conditions. Afr $J$ Biotechnol 6, 2868-2885.

12. Kang, C. H., Choi, Y. H., Choi, I. W., Lee, J. D. and Kim, G. Y. 2011. Inhibition of lipopolysaccharide-induced iNOS, COX-2, and TNF-a expression by aqueous extract of Orixa Japonica in RAW 264.7 cells via suppression of NF-kB activity. Trop J Pharm Res 10, 161-168.

13. Lee, S. Y., Kwon, H. K. and Lee, S. M. 2011. SHINBARO, a new herbal medicine with multifunctional mechanism for joint disease: first therapeutic application for the treatment of osteoarthritis. Arch Pharm Res 34, 1773-1777.

14. Miyataka, M., Rich, K. A., Ingram, M., Yamamoto, T. and Bing, R. J. 2002. Nitric oxide, anti-inflammatory drugs on renal prostaglandins and cyclooxygenase-2. Hypertension 39, 785-789.

15. Mitchell, J. A., Akarasereenont, P., Thiemermann, C., Flower, R. J. and Vane, J. R. 1993. Selectivity of nonsteroid anti-inflammatory drugs as inhibitors of constitutive and inducible cyclo-oxygenase. Proc Natl Acad Sci USA 90, 11693-11697.

16. Monaco, C., Andreakos, E., Kiriakidis, S., Mauri, C., Bicknell, C., Foxwell, B., Cheshire, N., Paleolog, E. and Feldmann, M. 2004. Canonical pathway of nuclear factor kappa B activation selectively regulates proinflammatory and prothrombotic responses in human atherosclerosis. Proc Natl Acad Sci USA 101, 5634-5639.

17. Nakanishi, M. and Rosenberg, D. W. 2013. Multifaceted roles of PGE2 in inflammation and cancer. Semin Immunopathol 35, 123-137.

18. Paek, M. K., Hwang, J. M., Jung, K. S., Kim, T. W., Kim, M. C., Lee, Y. J., Cho, Y. B., Park, S. W., Lee, H. S., Ku, D. S., Jeong, J. C., Kim, K. G., Choi, D. S., Shin, E. H., Jwang, J. H., Lee, J. S., Kim, S. S. and Bea, Y. S. 2010. Checklist of Korean Insects, pp. 36, Nature and Ecology: 
Seoul, Korea.

19. Park, J. Y., Heo, J. C., Woo, S. U., Yun, C. Y., Kang S. W., Hwang, J. S. and Lee, S. H. 2006. Anti-inflammatory and cellular protective effects on hydrogen peroxide-induced cytotoxicity of grasshopper extracts. Korean J Food Preserv 13, 796-802.

20. Rajendram, R., Saraswathy, S. and Rao, N. A. 2007. Photoreceptor mitochondrial oxidative stress in early experimental autoimmune uveoretinitis. Br J Ophthalmol 91, 531537.

21. Rao, C. V., Indranie, C., Simi, B., Manning, P. T., Connor, J. R. and Reddy, B. S. 2002. Chemopreventive properties of a selective inducible nitric oxide synthase inhibitor in colon carcinogenesis, administered alone or in combination with celecoxib, a selective cyclooxygenase-2 inhibitor. Cancer Res 62, 165-170.

22. Medzhitov, R. 2008. Origin and physiological roles of inflammation. Nature 454, 24

23. Salvemini, D., Milko, T. P., Masferrer, J. L., Seibert, K., Currie, M. G. and Needleman, P. 1993. Nitric oxide activates cyclooxygenase enzymes. Proc Natl Acad Sci USA 90, 7240-7244.

24. Shafran, Y., Zurgil, N., Afrimzon, E., Tauber, Y., Sobolev,
M., Shainberg, A. and Deutsch, M. 2012. Correlative analyses of nitric oxide generation rates and nitric oxide synthase levels in individual cells using a modular cell-retaining device. Anal Chem 84, 7315-7322.

25. Tak, P. P. and Firestein, G. S. 2001. NF-kappaB: a key role in inflammatory diseases. J Clin Invest 107, 7-11.

26. Swierkosz, T. A., Mitchell, J. A., Warner, T. D., Botting, R. M. and Vane, J. R. 1995. Co-induction of nitric oxide synthase and cyclo-oxygenase: interactions between nitric oxide and prostanoids. Br J Pharmacol 114, 1335-1342.

27. Hink, U. and Münzel, T. 2006. COX-2, another important player in the nitric oxide-endothelin cross-talk: good news for COX-2 inhibitors? Circ Res 98, 1344-1346.

28. Vane, J. R. 1971. Inhibition of prostaglandin synthesis as a mechanism of action for the aspirin-like drugs. Nature 231, 232-235.

29. Vlassara, H. 2005. Advanced glycation in health and disease role of the modern environment. Ann $N Y$ Acad Sci 1043, 452-460.

30. Wang, X., Luo, Y., Liao, W. B., Zhang, J. and Chen, T. M. 2013. Effect of osteoprotegerin in combination with interleukin-6 on inhibition of osteoclast differentiation. Chin J Traumatol 16, 277-280.

\title{
초록 : LPS로 유도된 RAW 264.7세포에 대한 벼메뚜기(Oxya chinensis sinuosa) 에탄올 추출물의 항염증 효과
}

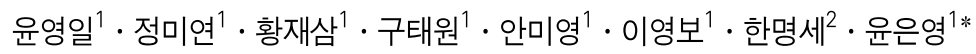 \\ (농촌진흥청 국립농업 과학원 농업생물부, ${ }^{2}$ 경북대학교 농생명과학대학 바이오섬유소재학과)
}

본 연구에서는 벼메뚜기 에탄올 추출물의 항염증 효능을 분석하기 위해 LPS로 염증 유도된 RAW 264.7 세포를 이용하였다. OCE의 항염증 효능을 확인 하기 위해서, 염증 유도된 RAW 264.7 세포에 대해 OCE 농도 의존적으로 염증성 사이토카인인 TNF-a와 IL-6의 유전자발현 및 단백질 생성을 감소시킴을 real-time PCR과 ELISA로 확인하 였다. 또한, NF-kB p65의 핵으로 이동이 차단됨을 면역형광염색으로 확인하였으며, iNOS와 COX-2 단백질 발현 을 감소시키는 것을 Western blot 분석으로 확인하였다. 이상의 연구결과를 통해 벼메뚜기는 염증에 의한 NF-kB p65의 활성과 TNF- $a$ 와 IL-6의 생성과 iNOS 및 COX-2의 발현을 억제하는 항염증 효능을 갖고 있는 것을 확인하 였다. 